\title{
The Harling Site (41FN1): An Ancestral Caddo Mound Site on the Red River in Fannin County, Texas
}

Timothy K. Perttula

Heritage Research Center, Stephen F. Austin State University

Follow this and additional works at: https://scholarworks.sfasu.edu/ita

Part of the American Material Culture Commons, Archaeological Anthropology Commons, Environmental Studies Commons, Other American Studies Commons, Other Arts and Humanities Commons, Other History of Art, Architecture, and Archaeology Commons, and the United States History Commons

Tell us how this article helped you.

This Article is brought to you for free and open access by the Center for Regional Heritage Research at SFA ScholarWorks. It has been accepted for inclusion in Index of Texas Archaeology: Open Access Gray Literature from the Lone Star State by an authorized editor of SFA ScholarWorks. For more information, please contact cdsscholarworks@sfasu.edu. 


\section{The Harling Site (41FN1): An Ancestral Caddo Mound Site on the Red River in Fannin County, Texas}

\section{Creative Commons License}

\section{(c) (1) \&}

This work is licensed under a Creative Commons Attribution-NonCommercial 4.0 International License 


\title{
The Harling Site (41FN1): An Ancestral Caddo Mound Site on the Red River in Fannin County, Texas
}

\author{
Timothy K. Perttula
}

\section{INTRODUCTION}

The Harling site (41FN1), also earlier known as the Morgan Place (see Suhm et al. 1954:177), is a little-known ancestral Caddo mound site located on the first alluvial terrace of the Red River in the northeastern corner of Fannin County in East Texas (Figures 1 and 2a-b). The only professional archaeological investigations at the Harling site took place in November-December 1960 by a University of Texas crew led by Dr. E. Mott Davis, in advance of proposed mound leveling by the landowner. Other than short summary articles by Davis (1962a, 1962b, 1996), the results of the excavations and analyses of the recovered artifacts from the Harling site have not been previously published. The mound at the site was leveled in 1963 by the landowner, Mr. R. A. Harling.

The single mound at the site was approximately $70 \times 52 \times 2.1 \mathrm{~m}$ in length, width, and height (Figure 2). There was a borrow pit area at the southern end of the mound.

The mound at the Harling site appears to be the westernmost known of the more than 100 Caddo mounds that have been reported in East Texas (Perttula 1993:251-252). According to Davis (1996:463), the site is on the western frontier of Caddo communities in the Red River valley, and Caddo settlements are found at most only a few miles to the west of the site along the river, but are common to the east of the Harling mound. Based on the 1960 excavations of the mound and an examination at that time of the surrounding alluvial landforms - which were plowed - there was no substantial Caddo settlement at the Harling site, or any associated settlement cluster within ca. $2.5 \mathrm{~km}$ of the mound, although there were scattered artifacts from the surface dispersed both east and west of the mound (see Figure 2b).

When R. L. Stephenson, E. O. Miller, and Lester Wilson visited the Harling site in August 1950, however, they commented that artifacts were abundant in the plowed fields around the mound. In particular they noted that the ceramic sherds were mostly plain and grog-tempered, and some of the sherds had a red slip (i.e., Sanders Plain). R. King Harris also collected artifacts from the site, primarily from an area to the west of the mound and near the edge of the alluvial terrace (see W on Figure 2b). He collected from this area W Gary dart points, Alba arrow points, plain sherds, and one Coles Creek Incised rim with an incised lip line. In the fields east of the mound, Harris collected a number of small triangular arrow points, suggesting that this area was where the latest Caddo occupation had taken place.

\section{EXCAVATIONS}

Davis (1962a:487-489, 1962b:86) indicated that the excavations in the Harling mound consisted of a "vertical section cut along the short axis of the mound from eastern edge to west of center." The vertical section was a maximum of $30 \mathrm{ft}$. (9.2 m) north-south (from N480-510) and $90 \mathrm{ft}$. (27.4 m) east-west (from W420-510) (Figure 3). The work was done by Mexican laborers or braceros, Curtis Tunnell, Robert Hoover, and Dr. E. Mott Davis.

Units excavated and screened in the vertical section were excavated in $0.5 \mathrm{ft}$. levels $(15 \mathrm{~cm})$ beginning at the surface of the mound: these included units at N500 W500; N495 W495; N495 W480; N495 W440; 


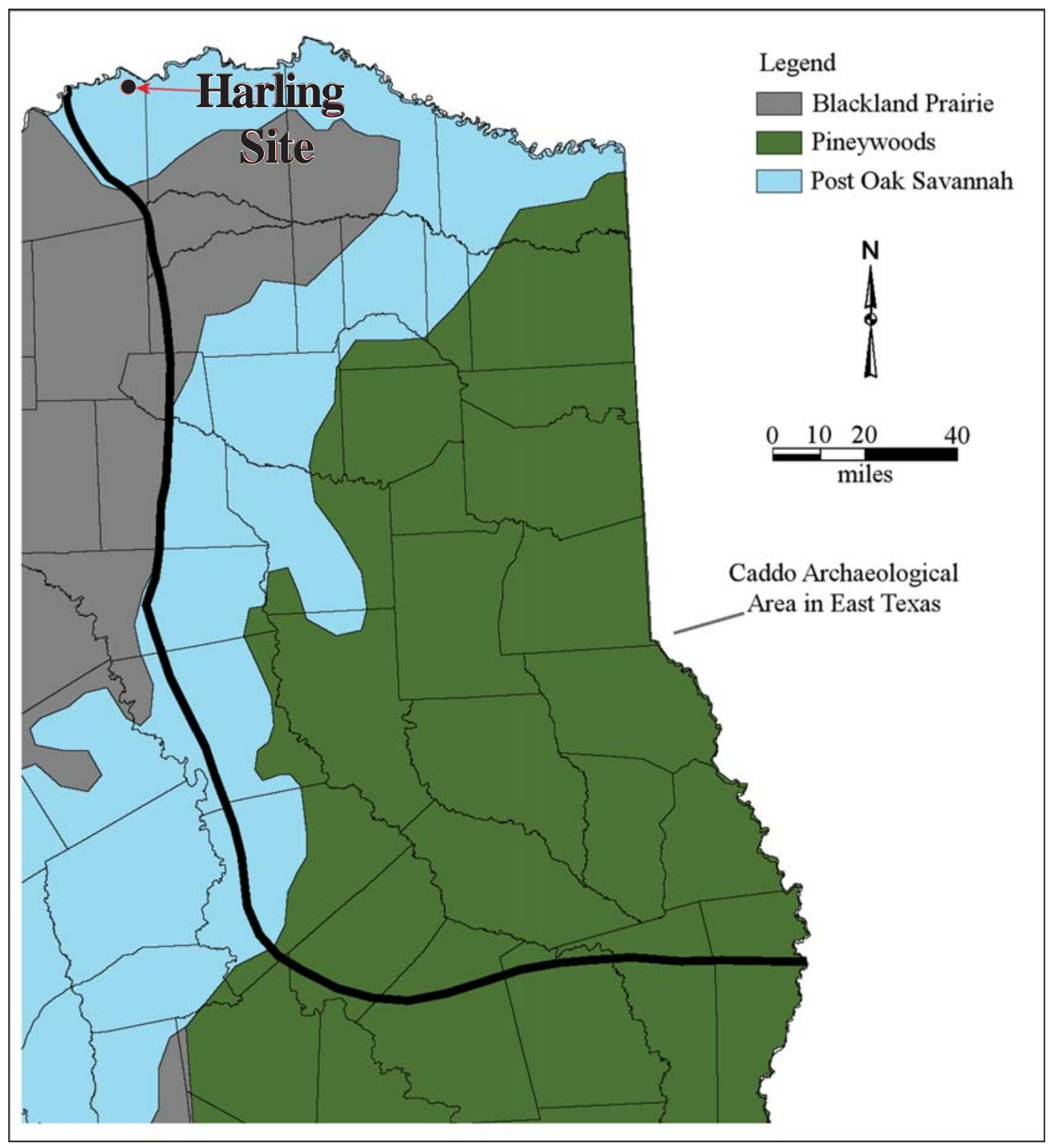

Figure 1. The location of the Harling site in East Texas.

N490 W490; N490 W480; N490 W470; N490 W460; N490 W440. Most units (n=9) were 10 x 10 ft. squares, but two other units at the eastern end of the mound were $10 \mathrm{x} 5 \mathrm{ft}$. in size (see Figure 3).

The recorded profiles of the mound excavations indicate that it was likely constructed in one stage of different sand and clay deposits on top of the ground surface/A-horizon. There was no evidence of structures or burial features in or on the mound, but beneath the mound in the A-horizon were baked and charcoal-stained areas that likely represent the remnants of burned Caddo structures or other constructed facilities; grogtempered and red-slipped grog-tempered sherds (i.e., Sanders Plain) were present in the buried A-horizon deposits. In the top of the mound were several pit features excavated into the existing mound; shell-tempered ceramic sherds were found in association with these pits and in the top $30 \mathrm{~cm}$ of the mound itself.

Several schematic mound profiles are provided in Figure 4. The profile at N503 W500 at the western end of the vertical cut section represents the best profile of the central part of the constructed mound. It has the following zones: a, plow zone, 106.1-105.0 ft. bs; b, tan (105.0-102.0 ft. bs), brown (102.0-100.9 ft. bs.), and grayish-brown to dark gray (100.9-99.0 ft. bs) sand and clay mound fill zones; c, dark gray to pale tan 

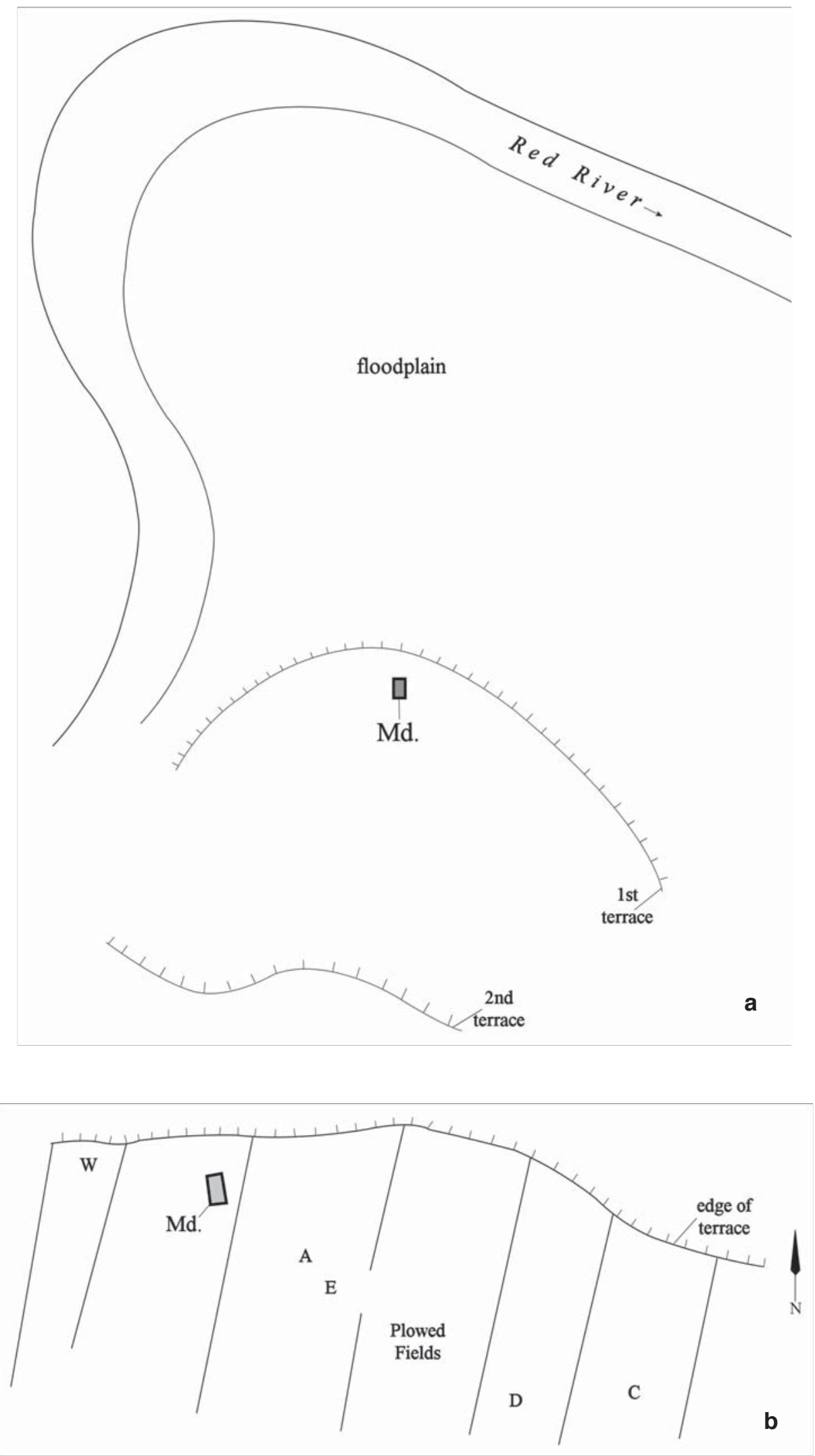

Figure 2. The setting of the Harling site: a, alluvial terraces relative to the channel of the Red River; $b$, the mound and surface artifact locations at the site. 


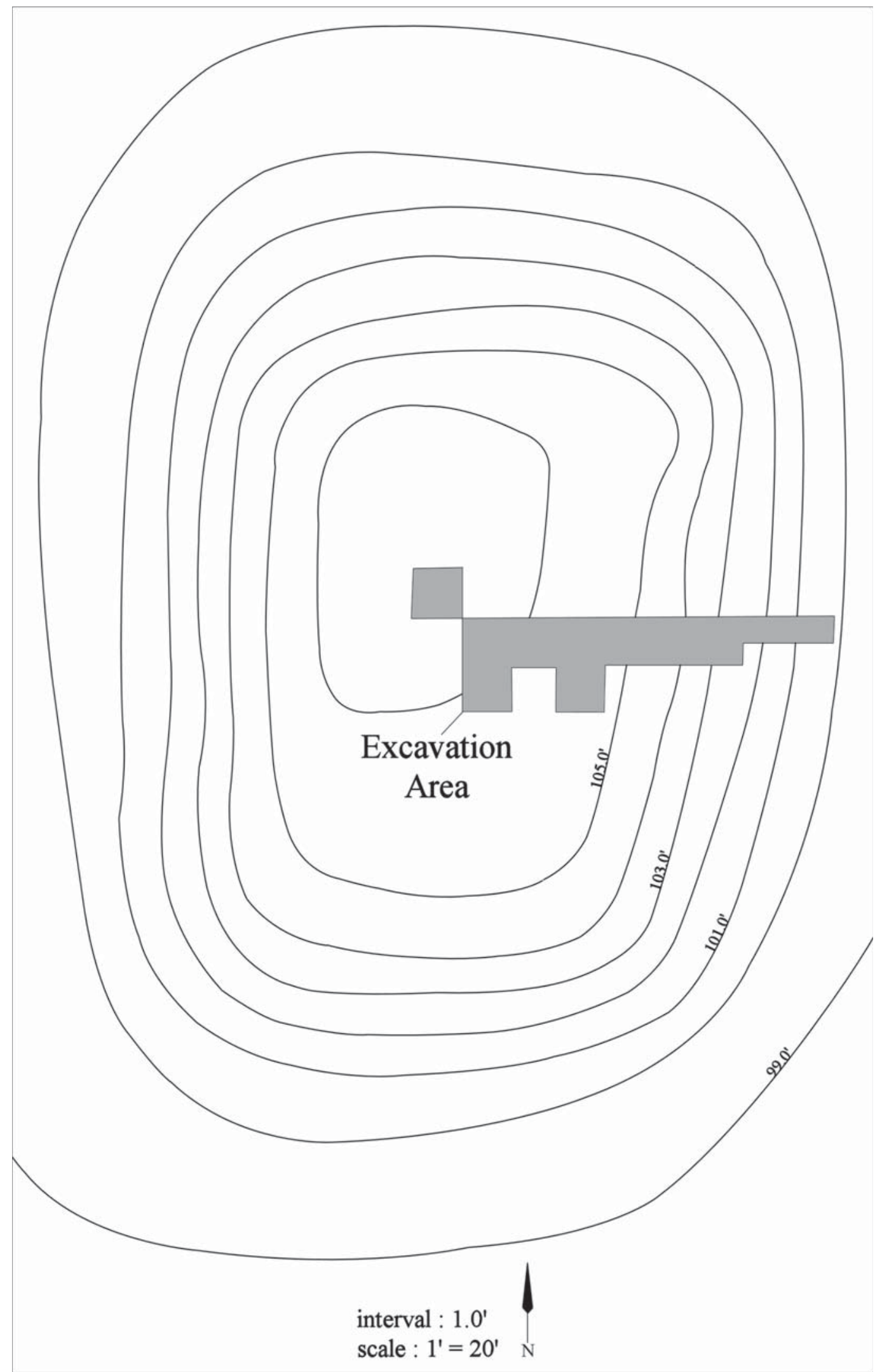

Figure 3. 1960 contour map of the mound at the Harling site and the location of the excavation units. 
A-horizon sand or original ground surface (99.0-97.9 ft. bs); and d, red clay B-horizon (97.9+ ft. bs). In the profile at N500 W490-500, the original ground surface/A-horizon was encountered at $99.1 \mathrm{ft}$. bs, 6.6 ft. $(2 \mathrm{~m})$ below the top of the mound. Mound fill zones in this part of the profile included tan and grayishbrown sand zones, one of which also had clay bands. In N490 W470, atop the buried A-horizon (at 99.6 $\mathrm{ft}$. bs, or $165 \mathrm{~cm} \mathrm{bs}$ ) was a $9.5 \mathrm{~cm}$ thick zone of dark reddish-brown sand with orange burned areas and charcoal flecks (Feature 91) (Figure 4). Farther east along the vertical cut section, at N500 W450-460, the grayish-tan buried A-horizon was encountered at $98.9 \mathrm{ft}$. bs $(140 \mathrm{~cm} \mathrm{bs})$. Resting on the buried Ahorizon was a $5 \mathrm{~cm}$ thick clay band/zone (Feature 84) that may represent a prepared floor to a structure; this feature covered an area at least $2.2 \times 1.6 \mathrm{~m}$ in length and width. There was a charcoal concentration (Feature 109) and hearth (61 cm in diameter) associated with Feature 84 in Unit N495 W440. Mound fill zones $(1.37 \mathrm{~m}$ in thickness, from 103.5-99.0 ft. bs), in this part of the mound were tan to dark tan in color with intermixed clay bands.

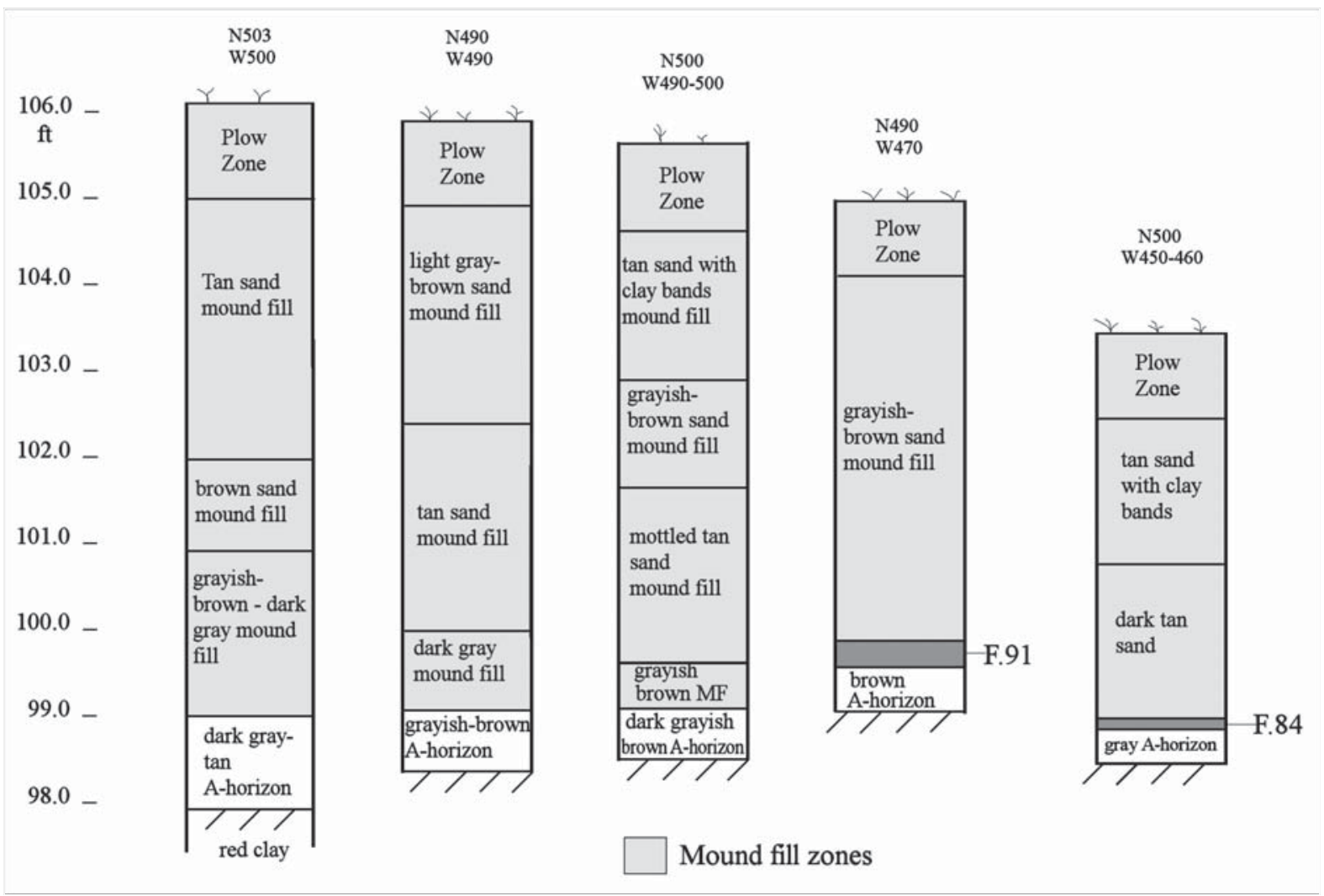

Figure 4. Schematic profiles of mound cross-sections at the Harling site.

Other features documented in the mound excavations included a hearth (Feature 91) in N490 W470, and four post hole stains in N480 W470; these were $20-28 \mathrm{~cm}$ in diameter, but did not form an obvious wall post hole pattern. An east-west line of three other post holes (10-15 cm in diameter) were noted in N495 W495 at $103.0 \mathrm{ft}$. bs. Feature 200, in Unit N480 W470, was a $56 \mathrm{~cm}$ diameter charcoal stain/hearth (with burned orange clay) in deposits underneath the mound itself.

Several test pits ( $5 \times 5 \mathrm{ft}$. in size) were excavated in the fields east of the mound, at N500 W320 and N500 W370. These test pits encountered a 15-24 cm thick plow zone overlying either a light brown sand A horizon ( $45 \mathrm{~cm}$ thick) in N500 W320 or a possible $27 \mathrm{~cm}$ thick midden zone (a dark grayish-brown sand) in N500 W370. This humic-stained soil zone overlay an orange sandy clay B-horizon whose top was at $51 \mathrm{~cm}$ bs. 


\section{INVESTIGATIONS}

The mound at the Harling site was leveled by the landowner in January 1963. Archaeologists J. R. Gipson and Robert Field of The University of Texas at Austin went to the site while the mound leveling was underway, but gained little useful information during bitterly cold weather, and with the ground frozen in places. Gipson did note (in records on file at TARL) that at least 10 historic burial features had been disturbed and/ or recorded during the leveling by the heavy machinery operators. Gipson also recorded one $30 \mathrm{~cm}$ diameter wood charcoal concentration (Feature I) in the west-southwest corner of the mound, at an elevation of $101.25 \mathrm{ft}$. bs; the depth of this charred wood concentration below the original ground surface is not known.

\section{ARTIFACT ASSEMBLAGE FROM THE HARLING SITE}

The artifact assemblage from the Harling site discussed herein primarily includes the diagnostic ceramic and lithic artifacts recovered from surface and excavated contexts at the site during the 1960 work by The University of Texas at Austin. The assemblage also includes a small collection of ceramic sherds and a ceramic pipe sherd found by R. K. Harris in the 1950s and eventually donated to TARL, which are primarily a surface collection from a field thought from the available notes to be west of the mound.

\section{Ceramic Sherds}

There are a total of 475 ceramic sherds in the TARL assemblage from the Harling site (Table 1). This includes plain sherds (88.2 percent), utility ware sherds (4.4 percent), and fine ware sherds ( 7.4 percent).

Table 1. Ceramic sherd assemblage from the Harling site.

\begin{tabular}{lccrr}
\hline Ware & Grog-tempered & Bone-tempered & Shell-tempered & N \\
\hline Plain & 194 & 43 & 182 & 419 \\
Utility & 15 & 4 & 2 & 21 \\
Fine & 25 & 2 & 8 & 35 \\
\hline Totals & 234 & 49 & 192 & 475 \\
\hline
\end{tabular}

About 49.3 percent of the plain and decorated sherds from the site are from grog-tempered vessels (see Table 1). More than 40 percent are from shell-tempered vessels, and the proportion of sherds from shelltempered vessels is considerable when compared to most of the more than 390 other ceramic assemblages in the East Texas Caddo sherd database (Perttula 2015a). The highest percentages of shell-tempered wares in East Texas Caddo sites occur in McCurtain phase sites (93-100 percent) downstream in Red River County, in a 15th-16th century site in the upper Sulphur River basin, and in a variety of ca. A.D. 1650-1830 Historic Caddo sites in the Red, upper Sabine, and Big Cypress Creek basins, including the Womack site (41LR1) (Perttula 2015a:Figure 12).

The plain ware sherds are tabulated in Table 2. The site's overall plain to decorated ratio is a very high 7.48 , indicating that plain wares are certainly well-represented in the ceramic assemblage from the Harling site. The number of plain rims ( $n=23,85$ percent of all the rims) in the assemblage is particularly notable, given that there are only three utility ware rim sherds and one fine ware rim sherd in the assemblage. 
Table 2. Plain ware sherds from the Harling site.

\begin{tabular}{lrrrr}
\hline Temper & Rim & Body & Base & N \\
\hline Grog & 8 & 171 & 15 & 194 \\
Bone & 4 & 31 & 8 & 43 \\
Shell & 11 & 159 & 12 & 182 \\
\hline Totals & 23 & 361 & 35 & 419 \\
\hline
\end{tabular}

There are several notable plain ware sherds in the Harling site ceramic assemblage. These include a grog-tempered rim from a surface collection that has a broad and flat lip, another grog-tempered rim with a scalloped lip, and a fragment of a grog-tempered effigy head; the effigy is probably that of a bird or duck. A similar ceramic effigy head sherd has been found at the Sanders site, but this was from a bone-tempered vessel and the exterior rim had been decorated with three broad horizontal engraved lines (Perttula et al. 2015).

Approximately 12 percent of the sherds $(n=56)$ from the Harling site have decorations (Table 3$)$. Between 12-17 percent of the grog- and bone-tempered sherds are decorated, compared to only 5 percent of the shell-tempered sherds. This difference suggests that the three distinct tempered wares are represented by different proportions of plain versus decorated vessels, but also that there are significant differences in the frequency with which vessels of differing tempers are decorated on their rim and/or body sections. Most of the grog- and shell-tempered sherds from the site are from fine ware vessels: 62.5 percent of the grogtempered sherds and 80 percent of the shell-tempered sherds.

Table 3. Decorated sherds in the Harling site ceramic assemblage.

\begin{tabular}{|c|c|c|c|c|}
\hline Decorative method & Grog & $\begin{array}{c}\text { Temper } \\
\text { Bone }\end{array}$ & Shell & $\mathrm{N}$ \\
\hline \multicolumn{5}{|l|}{ Utility ware } \\
\hline Brushed & 1 & 1 & - & 2 \\
\hline Incised & 13 & 2 & 1 & 16 \\
\hline Punctated, fingernail & 1 & - & - & 1 \\
\hline Punctated, tool & - & 1 & 1 & 2 \\
\hline Subtotal & 15 & 4 & 2 & 21 \\
\hline \multicolumn{5}{|l|}{ Fine ware } \\
\hline Engraved & 3 & - & 1 & 4 \\
\hline Red-slipped & 21 & 2 & 7 & 30 \\
\hline Trailed & 1 & - & - & 1 \\
\hline Subtotal & 25 & 2 & 8 & 35 \\
\hline Totals & 40 & 6 & 10 & 56 \\
\hline
\end{tabular}

Utility ware sherds (Table 4) are from vessels used for cooking and storage tasks at the site, almost always jars. The decorations are done on these vessels while they were still wet (i.e., before firing). These vessels are more coarsely tempered, and have thicker and more durable walls than most of the fine wares. They often have extensive areas of charred organic residues and sooting from use over an open fire. 
Table 4. Decorative elements on utility ware sherds from the Harling site.

\begin{tabular}{|c|c|c|c|c|c|c|c|}
\hline \multirow[b]{2}{*}{ Decorative element } & \multicolumn{2}{|c|}{ Grog } & \multicolumn{2}{|c|}{ Bone } & \multicolumn{2}{|c|}{ Shell } & \multirow[b]{2}{*}{$\mathrm{N}$} \\
\hline & rim & body & rim & body & rim & body & \\
\hline \multicolumn{8}{|l|}{ Brushed } \\
\hline parallel marks & - & 1 & - & 1 & - & - & 2 \\
\hline \multicolumn{8}{|l|}{ Incised } \\
\hline cross-hatched & - & 1 & - & - & - & - & 1 \\
\hline diagonal lines & 1 & 1 & - & - & - & - & 2 \\
\hline horizontal lines & $2 *$ & - & - & - & - & - & 2 \\
\hline $\begin{array}{l}\text { horizontal and diagonal } \\
\text { lines }\end{array}$ & - & - & - & 1 & - & - & 1 \\
\hline parallel lines & - & 6 & - & 1 & - & - & 7 \\
\hline straight line & - & 2 & - & - & - & 1 & 3 \\
\hline \multicolumn{8}{|l|}{ Punctated } \\
\hline fingernail, single & - & 1 & - & - & - & - & 1 \\
\hline tool, row/rows & - & - & - & 1 & - & 1 & 2 \\
\hline Totals & 3 & 12 & - & 4 & - & 2 & 21 \\
\hline
\end{tabular}

*one rim has an incised lip line

The majority of the utility wares are from vessels with incised decorative elements (76 percent, see Table 4), with punctated (14 percent) and brushed ( 9.5 percent) utility wares comprising the remainder of the small assemblage. The two grog-tempered brushed sherds in the utility ware sherds are probably from Bullard Brushed vessels made by Middle or Late Caddo potters in the upper Sabine and upper Cypress stream basins. The grog- and bone-tempered incised rim and body sherds are probably from Canton Incised vessels, except for the bowl rims with horizontal incised lines (see Table 4). Decorative elements represented include crosshatched lines (see Suhm and Jelks 1962:Plate 12c), diagonal opposed lines (see Suhm and Jelks 1962:Plate 12f-g), and horizontal and diagonal opposed lines (see Suhm and Jelks 1962:Plate 12a) (Figure 5a-b). One of the horizontal incised rim sherds is probably from a Davis Incised or Dunkin Incised vessel, but the other is from a Coles Creek Incised, var. unspecified vessel; it has a broad flat lip with an incised lip line.

The sherds with punctated decorative elements from grog- and bone-tempered vessels have one or more rows of punctations on the rim and/or the body of utility ware jars (see Table 4). The fingernail punctated body sherd is from a Monkstown Fingernail Impressed jar (see Suhm and Jelks 1962:Plate 55). The bonetempered tool punctated sherd may be from undefined punctated wares in the assemblage, or a variety of Monkstown where the punctations ate executed with wood tools rather than fingernail impressions. The shell-tempered tool punctated body sherd (see Table 4) is from a Late to Historic Caddo Emory PunctatedIncised jar (see Story et al. 1967).

The fine ware sherds from the Harling site include sherds from vessels that have engraved decorations that were executed when the vessel was leather-hard or already fired (Table 5). Also included in the fine wares are many red-slipped sherds, as these primarily are from bowls, bottles, and carinated bowls, typical fine ware vessel forms, rather than from utility ware jars, and trailed sherds; the trailed sherd is included because the design element suggests it is from a Keno Trailed vessel with a fine ware shape. 


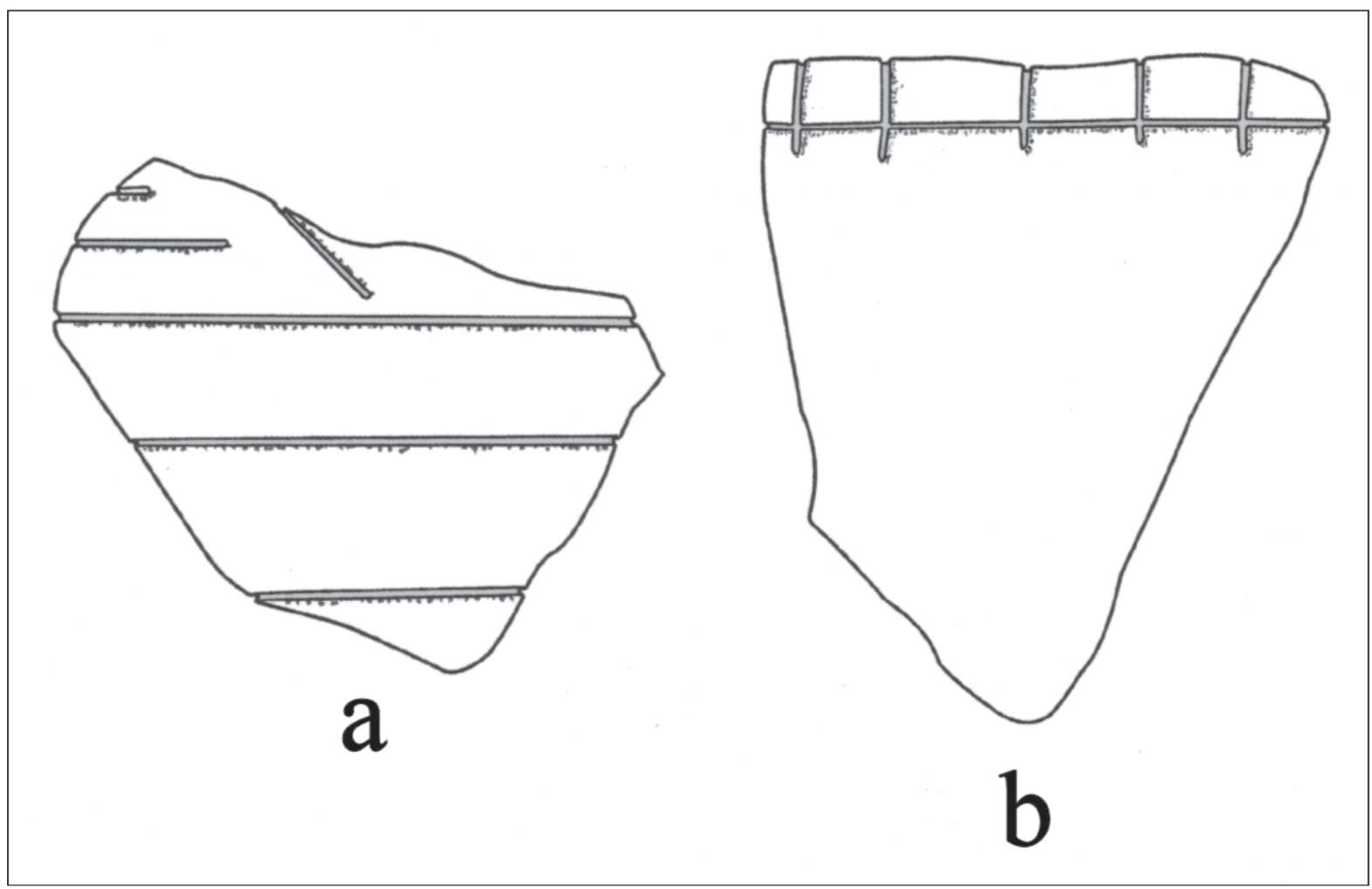

Figure 5. Incised sherds from the Harling site: a, R225, mound excavations; b, surface.

Table 5. Decorative elements on fine ware sherds from the Harling site.

\begin{tabular}{|c|c|c|c|c|c|c|c|}
\hline \multirow[b]{2}{*}{ Decorative element } & \multicolumn{2}{|c|}{ Grog } & \multicolumn{2}{|c|}{ Bone } & \multicolumn{2}{|c|}{ Shell } & \multirow[b]{2}{*}{$\mathrm{N}$} \\
\hline & rim & body & rim & body & rim & body & \\
\hline \multicolumn{8}{|l|}{ Engraved } \\
\hline hatched zone & - & 1 & - & - & - & - & 1 \\
\hline $\begin{array}{l}\text { horizontal and diagonal } \\
\text { lines }\end{array}$ & - & 1 & - & - & - & - & 1 \\
\hline parallel lines & - & 1 & - & - & - & 1 & 2 \\
\hline \multicolumn{8}{|l|}{ Red-Slipped } \\
\hline ext. slipped & - & 14 & - & 2 & - & 2 & 18 \\
\hline int./ext. slipped & 1 & 6 & - & - & - & 5 & 12 \\
\hline \multicolumn{8}{|l|}{ Trailed } \\
\hline straight trailed line & - & 1 & - & - & - & - & 1 \\
\hline Totals & 1 & 24 & - & 2 & - & 8 & 35 \\
\hline
\end{tabular}

Sherds with hatched zones and horizontal and diagonal engraved elements (see Table 5) are from Sanders Engraved carinated bowl and bowls (see Suhm and Jelks 1962:Plate 69). This is the principal fine ware in 
the Sanders phase component at the Sanders site (Perttula et al. 2015); the Sanders phase has been estimated to date from ca. A.D. 1100-1300 (Bruseth 1998), but it remains a poorly dated East Texas phase.

The red-slipped sherds from grog- and bone-tempered body vessels have a hematite-rich slip on both interior and exterior surfaces; they are probably from carinated bowls and bottles. These sherds are from Sanders Plain vessels, as redefined by Brown (1996:401-403 and Figures 2-191, 2-34g, 2-37a-1, 2-38d, 2-39d, k, n-q, and 2-42b). Sanders Plain is a grog-tempered, slipped, and otherwise undecorated type found widely across the Caddo area, including the middle reaches of the Red River and the upper Sabine River basin. Vessel forms include bowls, carinated bowls, and narrow and wide-mouthed bottles. PreA.D. 1400 ceramic assemblages where red-slipped sherds are relatively abundant are well represented at sites such as Jamestown (41SM54), Sam Kaufman (41RR16), A. C. Mackin (41LR31), and Sanders (41LR2) on the Sabine and Red rivers, respectively (Perttula 2015a:Figure 3). The shell-tempered redslipped sherds are likely from Late or Historic Caddo period Clement Redware bowls or carinated bowls (see Flynn 1976). Later ceramic assemblages, i.e., dating after A.D. 1400, with red-slipped sherds are found in these same areas, most notably in shell-tempered wares in McCurtain phase sites on the middle reaches of the Red River (see Perttula 2015a:Figure 3) and the ca. A.D. 1680-1740 components at the Sanders site (Perttula et al. 2015).

The one grog-tempered trailed body sherd (see Table 5) may be from a Keno Trailed bowl. In East Texas, sherds with trailed decorative elements are found in low percentages in ceramic assemblages in only a few parts of East Texas, principally in sites on the Red River (Perttula 2015a:Figure 4). These sites generally date between ca. A.D. 1400 (or later) and A.D. 1730. The highest proportion of trailed sherds in ceramic assemblages are found in various Texarkana phase village and mound areas at the Hatchel site (41BW3) on the Red River (Perttula 2014), well downstream from the Harling site.

\section{Ceramic Pipe Sherd}

One pipe stem sherd from a long-stemmed Red River style ceramic pipe (see Hoffman 1967) was in the R. K. Harris collection. The pipe stem sherd had no visible temper inclusions.

\section{Chipped Stone Tools}

In addition to expedient flake tools and a few biface fragments, which were not analyzed as part of this study, there are dart points $(n=5)$, arrow points $(n=7)$, and unifacial scrapers $(n=14)$ in the chipped stone tools from the Harling site. The tools are made from local high-quality Red River cherts and coarse-grained quartzite, as well as Ouachita Mountains novaculite.

The dart points include four contracting stem Gary points from surface contexts and one gray chert dart point with an expanding stem, a convex base, and short barbs. This may be a Godley point. These few dart points are evidence of some use of the Red River alluvial terrace during Woodland period times.

Six of the seven arrow points are triangular arrow points with shallow concave bases, much like Late Caddo style Maud points as well as late 17th-mid-18th century Fresno arrow points from Historic Caddo sites in East Texas (Allen et al. 1967:Figure 68f-g), including the nearby Sanders site (Perttula et al. 2015:Figure 17a-m) and the Womack site (41LR1, Harris et al. 1965). These points are either found in the top or first level of excavations in the mound at Harling, on the mound surface, and in the cultivated field southeast of the mound.

The scraping tools in the Harling site collections include end scrapers $(n=2)$, side scrapers $(n=7)$, end-side scrapers $(n=4)$, and bilateral side scrapers or side scrapers with two working edges $(n=1)$. The frequency of scraping tools in the tool assemblage is clear evidence that the processing of hides was an important activity 
during the ancestral Caddo occupations at the Harling site. The scraping tools were either found in surface contexts in the fields southeast of the mound, on the mound surface, or in near-surface levels in N490 W490 $(n=4)$ in the mound excavations, suggesting that the most intensive use of scraping tools took place during the latest Caddo occupation, an occupation that may date from after ca. A.D. 1680.

\section{Ground Stone Tool}

The R. King Harris collection of surface artifacts from the Harling site has a petaloid celt with a polished bifacial bit (Figure 6). The celt is made from Ouachita Mountains greenstone.

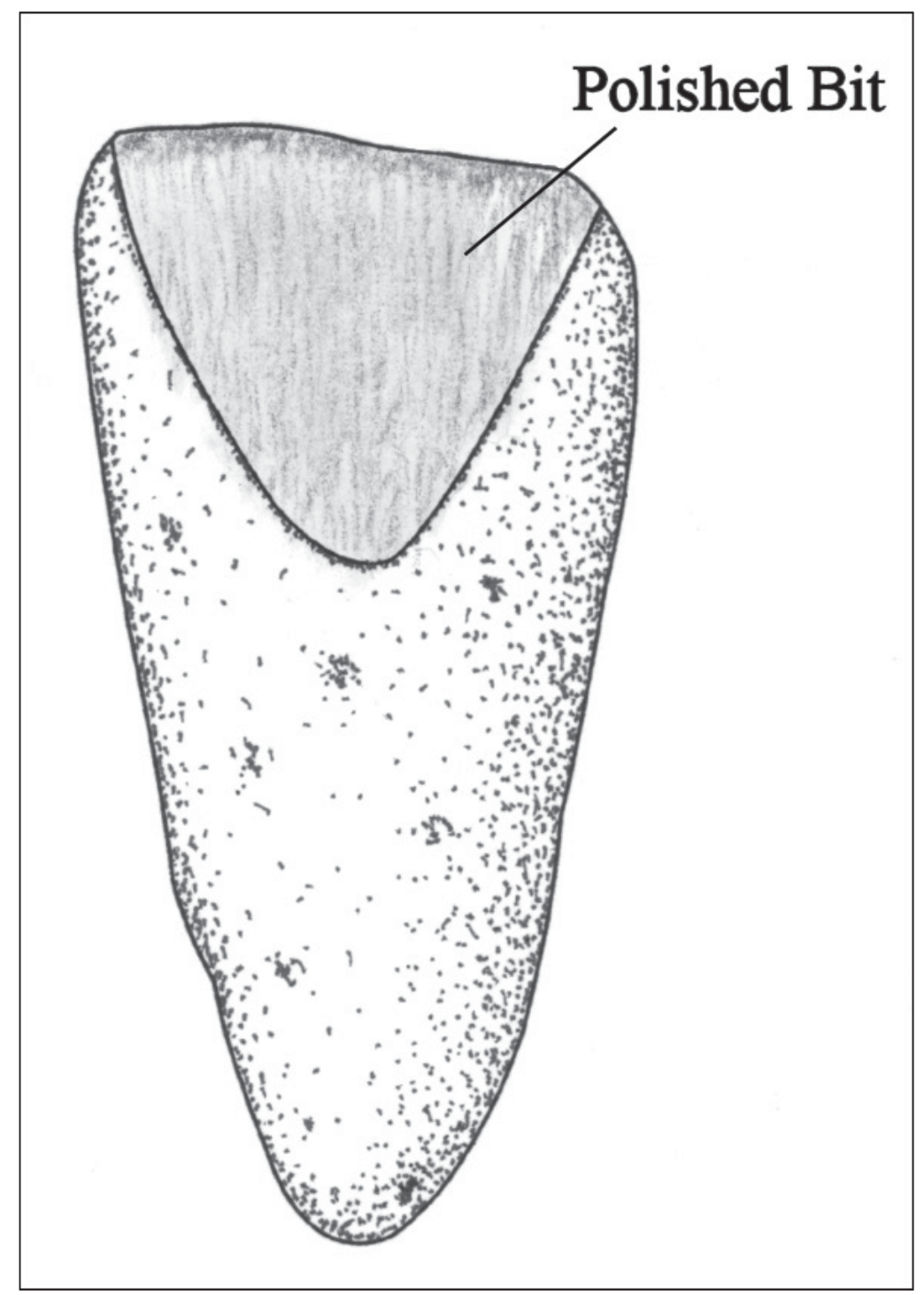

Figure 6. Petaloid celt from the Harling site, R. K. Harris collection.

\section{Glass bead}

A single glass bead had been collected from the surface of the Harling site, in Area A southeast of the mound (see Figure 2b). It is no longer in the collections at TARL, but inventory notes describe it as a blue faceted bead that was $6 \mathrm{~mm}$ in length and $7 \mathrm{~mm}$ in diameter. 


\section{RADIOCARBON DATES}

Three samples of wood charcoal or unburned animal bone from the mound excavations were submitted to DirectAMS for radiocarbon dating. They include: (1) a small piece of unburned bone from Feature 43, a dog skeleton near the top of the mound's deposits in Unit N490 W490, in the first level in the unit (surface to $105.0 \mathrm{ft}$. bs); (2) one deer teeth from the second level in N500 W500, between 105-104 ft. bs; and (3) a concentration of wood charcoal from Feature I near the top of the mound.

Table 6. Radiocarbon dates from the Harling site.

\begin{tabular}{|c|c|c|c|c|}
\hline $\begin{array}{l}\text { Lab No.* } \\
\text { and Depth/ } \\
\text { Lot No. }\end{array}$ & $\begin{array}{l}\text { Conventional } \\
\text { Radiocarbon age } \\
\text { (B.P.) }\end{array}$ & $\begin{array}{l}1 \text { sigma } \\
\text { Calibrated } \\
\text { age range }\end{array}$ & $\begin{array}{l}2 \text { sigma } \\
\text { Calibrated } \\
\text { age range }\end{array}$ & $\begin{array}{l}\text { Median } \\
\text { calibrated age }\end{array}$ \\
\hline $\begin{array}{l}006767, \\
\text { Feature I** } \\
(\mathrm{R} 232)\end{array}$ & $114 \pm 22$ & $\begin{array}{l}\text { AD 1692-1709 } \\
(0.11), \text { AD } 1718- \\
1728(0.06), \text { AD } \\
1812-1889(0.46), \\
\text { AD 1910-1921 } \\
(0.06)\end{array}$ & $\begin{array}{l}\text { AD 1682- } \\
1736(0.28) \\
\text { AD } 1805- \\
1935(0.68)\end{array}$ & AD 1839 \\
\hline $\begin{array}{l}006765, \\
\text { Feature } 43 \\
\text { (R43) }\end{array}$ & $295 \pm 24$ & $\begin{array}{l}\text { AD } 1523-1572 \\
(0.49), \text { AD } 1630- \\
1648(0.19)\end{array}$ & $\begin{array}{l}\text { AD 1513- } \\
1601(0.66), \\
\text { AD 1616- } \\
1654(0.28)\end{array}$ & AD 1561 \\
\hline $\begin{array}{l}006766, \\
\text { deer teeth } \\
(\mathrm{R} 109 \mathrm{~B})\end{array}$ & $526 \pm 20$ & $\begin{array}{l}\text { AD 1407-1427 } \\
(0.68)\end{array}$ & $\begin{array}{l}\text { AD 1396- } \\
1437(0.92)\end{array}$ & AD 1416 \\
\hline
\end{tabular}

*Direct-AMS Lab **collected in 1963

Based on the calibrated age of the wood charcoal from Feature I, it is likely that this date reflects historic Anglo-American activities associated with the initial clearing of vegetation from the mound, and it is not the product of any ancestral Caddo activities at the Harling mound. The other two calibrated dates, however, suggest use of the mound during the early historic period, preceding the Womack phase (Perttula 2015b), probably in the latter part of the 16th century to early 17th century, and earlier during the Middle Caddo period Sanders phase occupation of the site. The median calibrated age of the deer teeth is A.D. 1416 (see Table 6). More dates are needed from cultural features at various depths in and immediately below the mound to more definitively establish the age and construction span of the Harling mound

\section{AGE AND AFFILIATION OF THE SITE}

The first use of the Harling site appears to have been during the Woodland period (ca. 500 B.C. to A.D. 800). This occupation is marked by the presence of a few Gary dart points and a possible Godley dart point; the occupation was not extensive.

The occupation of the site was more substantial by ancestral Caddo groups. The initial occupation by Caddo peoples took place during the Middle Caddo period, when the earthen mound at the Harling site was constructed. The recorded profiles of the mound excavations at the Harling site indicate that it was likely constructed in one stage of different sand and clay deposits on top of the ground surface/A-horizon. There 
was no evidence of structures or burial features in or on the mound, but beneath the mound in the A-horizon were baked and charcoal-stained areas that likely represent the remnants of burned Caddo structures or other constructed facilities; grog-tempered and red-slipped grog-tempered sherds (i.e., Sanders Plain) were present in the buried A-horizon deposits. In the top of the mound were several pit features excavated into the existing mound; shell-tempered ceramic sherds were found in association with these pits and in the top $30 \mathrm{~cm}$ of the mound itself. These pit features are part of an historic Caddo use of the site. Two calibrated dates, from the mound, also suggest use of the mound during the early historic period, preceding the Womack phase (Perttula 2015b), probably in the latter part of the 16th century to early 17th century, and earlier during the Middle Caddo period Sanders phase occupation of the site. The median calibrated age of the dated sample from a Middle Caddo period context is A.D. 1416.

\section{SUMMARY AND CONCLUSIONS}

The Harling site (41FN1) is the westernmost known ancestral Caddo mound center on the Red River in East Texas. The site has one flat-topped earthen mound that stood $2.1 \mathrm{~m}$ in height. Prior to the leveling of the mound by the landowner (in 1963), a University of Texas at Austin team of archaeologists and local laborers led by E. Mott Davis investigated the mound in 1960 through the excavation of several trenches cut into the mound, as well examined the surrounding site area for evidence of associated habitation deposits.

These investigations indicated that the mound was built of intermixed clay and sand zones over a premound surface that apparently had burned Caddo structures. There were no structures or cultural features within the mound itself. Recovered material culture remains and one radiocarbon date suggests that the premound cultural features are part of a Middle Caddo period Sanders phase occupation; the mound was also built over these cultural features at this time, around ca. A.D. 1400. A later use of the mound took place in the 17th and possibly early 18th century by Caddo peoples, during the Womack phase, who dug a series of pits in the top of the mound for an unknown purpose. An associated habitation area southeast of the mound itself has triangular arrow points, scrapers, and a single glass bead.

A notable feature of the material culture remains from the Harling site is the high proportion of plain and decorated shell-tempered ceramic wares; these are part of the Womack phase occupation. The only identified types in the shell-tempered assemblage are Emory Punctated-Incised and Clement Redware. The earlier Sanders phase ceramic sherds are from grog- and bone-tempered utility ware and fine ware vessels. As part of this earlier ceramic assemblage, there are sherds from Canton Incised, Monkstown Fingernail Impressed, Sanders Engraved, and Sanders Plain (being particularly abundant) vessels.

\section{ACKNOWLEDGMENTS}

I want to thank Jonathan Jarvis of the Texas Archeological Research Laboratory at the University of Texas at Austin for providing access to the collections and records from the Harling site. Lance Trask prepared the figures in this article.

\section{REFERENCES CITED}

Allen, G. L., Jr., P. Allen, J. F. Cochran, L. F. Duffield, R. E. Forrester, Jr., E. D. Helm, I. R. Lobdell, D. Lubell,

R. E. Padgett, and R. L. Tapscott

1967 Stone Tools. In "The Gilbert Site: A Norteno Focus Site in Northeast Texas," edited by E. B. Jelks. Bulletin of the Texas Archeological Society 37:191-211. 
Brown, J. A.

1996 The Spiro Ceremonial Center. The Archaeology of Arkansas Valley Caddoan Culture in Eastern Oklahoma. 2 Vols. Memoir No. 29. Museum of Anthropology, University of Michigan, Ann Arbor.

Bruseth, J.E.

1998 The Development of Caddoan Polities along the Middle Red River Valley of Eastern Texas and Oklahoma. In The Native History of the Caddo: Their Place in Southeastern Archeology and Ethnohistory, edited by T. K. Perttula and J. E. Bruseth, pp. 47-68. Studies in Archeology 30. Texas Archeological Research Laboratory, The University of Texas at Austin.

Davis, E. M.

1962a Archaeological Salvage Investigations of the Harling Mound in Fannin County, Texas. American Philosophical Society Yearbook 1961:487-489.

1962b The Harling Site (41FN1), Fannin County, Texas. Plains Anthropologist 7(16):86.

1996 Harling Site. In The New Handbook of Texas, Vol. 3, edited by R. Tyler, pp. 462-463. Texas State Historical Association, Austin.

Flynn, P.

1976 A Study of Red-Filmed Pottery from the Clement Site (Mc-8), McCurtain County, Oklahoma. Bulletin of the Oklahoma Anthropological Society 25:127-134.

Harris, R. K., I. M. Harris, J. C. Blaine, and J. Blaine

1965 A Preliminary Archeological and Documentary Study of the Womack Site, Lamar County, Texas. Bulletin of the Texas Archeological Society 36:287-363.

Hoffman, M. E.

1967 Ceramic Pipe Style Chronology Along the Red River Drainage in Southwestern Arkansas. The Arkansas Archeologist 8(1):4-14.

Perttula, T. K.

1993 Mound Sites in Northeast Texas and Northwest Louisiana. In Archeology in the Eastern Planning Region, Texas: A Planning Document, edited by N. A. Kenmotsu and T. K. Perttula, pp. 251-252. Cultural Resource Management Report 3. Department of Antiquities Protection, Texas Historical Commission, Texas.

2014 Archaeological Studies of the Hatchel Site (41BW3) on the Red River in Bowie County, Texas. Special Publication No. 23. Friends of Northeast Texas Archaeology, Austin and Pittsburg.

2015a East Texas Caddo Ceramic Sherd Database. Journal of Northeast Texas Archaeology 51, in press.

2015b The Womack Site (41LR1), an Ancestral Caddo Settlement on the Red River in Lamar County, Texas. Journal of Northeast Texas Archaeology 52, in press.

Perttula, T. K., B. Nelson, M. Walters, and R. Z. Selden Jr.

2015 The Sanders Site (41LR2): A Middle to Historic Caddo Settlement and Mound Center on the Red River in Lamar County, Texas. Journal of Northeast Texas Archaeology 50, in press.

Story, D. A., B. Barber, E. Cobb, H. Cobb, R. Coleman, K. Gilmore, R. K. Harris, and N. Hoffrichter

1967 Pottery Vessels. In "The Gilbert Site: A Norteno Focus Site in Northeast Texas," edited by E. B. Jelks. Bulletin of the Texas Archeological Society 37:112-187.

Suhm, D. A. and E. B. Jelks (editors)

1962 Handbook of Texas Archeology: Type Descriptions. Special Publication No. 1, Texas Archeological Society, and Bulletin No. 4, Texas Memorial Museum, Austin. Reprinted in 2009, Gustav's Library, Davenport, Iowa.

Suhm, D. A., A. D. Krieger, and E. B. Jelks

1954 An Introductory Handbook of Texas Archeology. Bulletin of the Texas Archeological Society 25:1-562. 